\title{
CHANGES IN SOIL MICROBIAL RESPIRATION AND PHYSICOCHEMICAL PROPERTIES FOLLOWING BONNY LIGHT CRUDE OIL CONTAMINATION OF SANDY LOAM SOIL
}

\author{
*Eze, C. N. ${ }^{1}$, Orjiakor, P. I. ${ }^{2}$ and Ebeifenadi, U. J. ${ }^{1}$ \\ ${ }^{1}$ Department of Microbiology,University of Nigeria Nsukka. \\ ${ }^{2}$ Department of Microbiology, Ekiti State University, Ado-Ekiti. \\ *Author for correspondence, email: chibuzor.eze@unn.edu.ng, Tel: 08151510547 \\ (Received: 25 ${ }^{\text {th }}$ November, 2019; Accepted: 31 ${ }^{\text {st }}$ March, 2020)
}

\section{ABSTRACT}

\begin{abstract}
This study was undertaken to investigate the effects of Bonny light crude oil contamination of sandy loam soil on aspects of microbial metabolism and physicochemical properties of the soil. Bonny light crude oil (specific gravity $=0.81)$ was used at eight different levels $(0.5 \%, 1.0 \%, 2.0 \%, 2.5 \%, 5.0 \%, 10.0 \%, 15.0 \%$ or $20.0 \% \mathrm{v} / \mathrm{w}$ of soil) for the controlled pollution of pristine soil samples, each weighing $1 \mathrm{~kg}$. The experiment lasted for eight weeks. Results of the effects of crude oil on the physicochemical properties of the soil showed that high levels of the oil significantly $(\mathrm{p}<0.05)$ increased soil organic matter but had no significant effect on the $\mathrm{pH}$ and moisture content. With the exception of organic carbon, the levels of bioavailable nitrogen, sodium, potassium, calcium, magnesium, sulphur and phosphorus in the test samples with higher levels of crude oil $(5.0 \%, 10.0 \%$, $15.0 \%$ and $20.0 \%$ ) were significantly reduced when compared to their levels in the controls. Similarly, higher levels of the oil significantly $(\mathrm{p}<0.05)$ reduced soil microbial phospholipid synthesis and $\mathrm{CO}_{2}$ emission. Correlation analysis using the Pearson's correlation model showed a positive correlation between soil $\mathrm{CO}_{2}$ and phospholipid $(\mathrm{r}=0.74)$.
\end{abstract}

Keywords: Contamination, Crude oil, Microbial respiration, Physicochemical properties.

\section{INTRODUCTION}

Crude oil pollution of the environment is a global problem which has meted out untold havoc on the ecosystem. Even though crude petroleum since its discovery as an energy source has greatly improved man's living conditions, the everincreasing damages it wreaks on the ecosystem underscore its role as a potent environmental pollutant. It has been shown to negatively affect both the biotic and abiotic components of the ecosystem (McOrist and Lenghaus, 1992; Chaineau et al., 2000; Adoki and Orugbani, 2007; Mariana et al., 2010; Eze et al., 2013; Sulaiman et al., 2015; Ikuesan, 2017; Odo et al., 2019). The toxicity of crude and refined oil products to living organisms is an issue that needs urgent attention, especially in oil-rich nations of the world. In areas of heavy oil exploration and exploitation, ecologists have noted a drastic decline in the population of many plant and animal species as well as a sharp depletion in the fertility of agricultural lands (McOrist and Lenghaus 1992).

In Nigeria for instance, oil spill is a major environmental problem. According to information from the Department of Surveying and Geoinformatics, University of Lagos, between 1976 and 1996, Nigeria recorded a total of 4,835 oil spill incidents which resulted in the loss of $1,896,960$ barrels of oil to the environment. In 1998, still in Nigeria, 40,000 barrels of oil from Mobil platform off the Akwa Ibom coast were spilled into the environment causing serious damage to the coastal environment. Oil spillage along the Nigerian coasts has severely affected the flora, fauna, drinking water as well as human lives and property in those regions. Because of the perennial nature of crude oil pollution, painstaking research on the mechanisms by which it negatively affects living and non-living matter is necessary to help design remediation techniques for contaminated environments. Many researchers have delved into the effects of crude oil pollution on living organisms but to date, there is paucity of research information on the effects of this natural resource on arable lands. To this end this study was undertaken to investigate some of the ways by which crude oil negatively impacts on the soil as well as on microbial respiration. 


\section{MATERIALS AND METHODS}

The major materials used in the study were:

1) Bonny light crude oil which was obtained from the Nigerian National Petroleum Corporation (NNPC) Port Harcourt Refinery, Alesa-Eleme, Rivers State, Nigeria.

2) Pristine sandy loam soil collected from Botanical Garden, University of Nigeria, Nsukka.

\section{Experimental Design}

The study was grouped into two phases. The first phase investigated the effects of crude oil on microbial metabolism which consisted of its effects on soil microbial respiration and phospholipids synthesis. The second phase was about the effects of crude oil on the physicochemical properties of the soil.

Bonny light crude oil (specific gravity $=0.81$ ) was used at eight different levels $(0.5 \%, 1.0 \%, 2.0 \%$, $2.5 \%, 5.0 \%, 10.0 \%, 15.0 \%$ or $20.0 \% \mathrm{v} / \mathrm{w}$ of soil) for the controlled contamination of pristine soil samples, each weighing $1 \mathrm{~kg}$. The control soil samples were not contaminated. Each experiment lasted for eight weeks.

\section{Determination of the Effects of Crude Oil on Soil Microbial Respiration}

This was done by following the method of Isermeyer (1952) which quantified the level of $\mathrm{CO}_{2}$ evolved from the soil. Fifty grams (50 g) of each soil sample was weighed in duplicate into beakers placed inside jars with air-tight covers. Twenty-five millilitres $(25 \mathrm{ml})$ of $0.05 \mathrm{M} \mathrm{NaOH}$ was pipetted into each jar and immediately the jars were made airtight with rubber rings. Three jars containing $0.05 \mathrm{M} \mathrm{NaOH}$ but without soil were used as controls for both contaminated and uncontaminated soil samples. Thereafter all jars were incubated for 3 days at $25{ }^{\circ} \mathrm{C}$ (room temperature).

\section{Estimation of $\mathrm{CO}_{2}$}

At the end of the incubation, the jars were opened and the beakers taken out. The external surface of each beaker was washed with $\mathrm{CO}_{2}$ free water (prepared by cooling boiled distilled water in a container with $\mathrm{CO}_{2}$ absorption tubes) to wash the
$\mathrm{NaOH}$ solution completely into the jar. Thereafter, $5 \mathrm{ml}$ of $0.5 \mathrm{M}$ barium chloride solution was added to each jar together with some drops of phenolphthalein indicator. A $0.05 \mathrm{M} \mathrm{HCl}$ was added drop wise with continuous stirring until the colour changed from red to colourless.

Calculation of results:

The rate of the respiration was calculated by the following relationship:

$$
\mathrm{CO}_{2}(\mathrm{mg}) / \mathrm{SWt}=\frac{\left(\mathrm{V}_{\mathrm{o}}-\mathrm{V}\right) \times 1.1}{\mathrm{DWT}}
$$

Where SWt is the amount of soil dry weight in grams, $\mathrm{T}$ is the incubation time in hours, $\mathrm{V}_{\mathrm{o}}$ is the volume of $\mathrm{HCl}$ used for blank titration (average value) in milliliters. $\mathrm{V}$ is the volume of $\mathrm{HCl}$ used for the soil sample (average value), DWT is the dry weight of $1 \mathrm{~g}$ moist soil and 1.1 is the conversion factor ( $1 \mathrm{ml} 0.05 \mathrm{M} \mathrm{NaOH}$ equals $\left.1.1 \mathrm{mg} \mathrm{CO}_{2}\right)$.

\section{Determination of Microbial Phospholipids}

This was done by the method of Frostegard et al. (1991). Glassware was washed in methanol, 15\% $\mathrm{HNO}_{3}$ and rinsed twice in tap water and three times in deionized water. Extraction of phospholipids was achieved using a chloroform: methanol: citrate buffer $(1: 2: 0.8, \mathrm{v} / \mathrm{v} / \mathrm{v})$ as extractant. The citrate buffer contained $0.015 \mathrm{M}$ citric acid and $0.15 \mathrm{M}$ trisodium citrate $(5.9: 4.1 \mathrm{v} / \mathrm{v})$ producing a $\mathrm{pH}$ of 4.0 . One gram of wet weight of soil was placed in a McCartney bottle with $11.65 \mathrm{ml}$ of extractant. The ratio of chloroform to soil was 3:1; within the range of $2-$ 6: 1 used by Frostegard et al. (1991). After 2 hours, $3.1 \mathrm{ml}$ of citrate buffer and $3.1 \mathrm{ml}$ of chloroform were added and the solution periodically shaken throughout a further hour to assist extraction. Solutions were then left overnight to separate into two phases. Part of the lower chloroform phase (6.4 $\mathrm{ml}$ final volume) was withdrawn with a pipette, using care to avoid the inclusion of any soil particles and placed in a small vial. A $0.1-1.0$ $\mathrm{ml}$ aliquot was then transferred to a $5 \mathrm{ml}$ bijou bottle and dried with nitrogen gas.

Digestion and phospholipids analysis were performed as described by Findlay et al. (1989). Lipid extracts and glycerol phosphate standards were digested with $1.8 \mathrm{ml}$ acidified potassium persulphate $\left(\mathrm{K}_{2} \mathrm{~S}_{3} \mathrm{O}_{8}\right)$ solution $(5 \mathrm{~g}$ to $100 \mathrm{ml}$ of 
$0.35 \mathrm{~N} \mathrm{H}_{2} \mathrm{SO}_{4}$ ) for $24 \mathrm{~h}$ at $95^{\circ} \mathrm{C}$. While still hot, 0.4 $\mathrm{ml}$ of ammonium molybdate solution $(2.5 \%$ $\left(\mathrm{NH}_{4}\right)_{6} \mathrm{MO}_{7} \mathrm{O}_{24}$ in $\left.5.72 \mathrm{~N} \mathrm{H}_{2} \mathrm{SO}_{4}\right)$ was added and left for $10 \mathrm{~min}$ before the addition of $1.8 \mathrm{ml}$ of malachite green solution. Absorbance at $610 \mathrm{~nm}$ was read after $30 \mathrm{~min}$. Distilled water was used as blank.

\section{Determination of Total Organic Carbon and $\%$ Organic Matter in Soil}

The method of Walkley-Black (1934) was followed. One gram of each soil sample was weighed into a $250 \mathrm{ml}$ conical flask. A $10.0 \mathrm{ml}$ I N $\mathrm{K}_{2} \mathrm{Cr}_{2} \mathrm{O}_{7}$ solution was pipettted accurately into each flask and swirled gently to disperse the soil. Thereafter, $20 \mathrm{ml}$ of $0.05 \mathrm{M} \mathrm{H}_{2} \mathrm{SO}_{4}$ was rapidly added by means of a pipette. The flask was immediately swirled until soil and reagents were mixed and left to stand on white tile for about 30 minutes. This was followed by addition of $100 \mathrm{ml}$ of distilled water. Finally three drops of orthophenanthroline indicator (made by dissolving $14.8 \mathrm{~g}$ of 0 -phenanthroline monohydrate and $6.9 \mathrm{~g}$ of $\mathrm{FeSO}_{4} .7 \mathrm{H}_{2} \mathrm{O}$ in 1 litre of distilled water) was added. This was titrated with acidified $0.5 \mathrm{~N}$ ferrous sulphate solution (14 $\mathrm{g} / \mathrm{L}$ of water containing $15.0 \mathrm{ml} 0.05 \mathrm{M} \mathrm{H}_{2} \mathrm{SO}_{4}$ ). The ferrous sulphate was added drop by drop until the colour changed from blue to red (maroon colour) in reflected light against the white background.

The results were calculated according to the following formula:

$$
\begin{aligned}
& \% \text { Organic carbon in soil }= \\
& \frac{\left(\mathrm{MeK}_{2} \mathrm{Cr}_{7}-\mathrm{MeFeSO}_{4}\right) \times 0.003 \times 100 \times \mathrm{F}}{\text { g of air }-\mathrm{dry} \text { soil }} \\
& \text { Correction factor, } \mathrm{F}=1.33 \\
& \mathrm{Me}=\text { Normality of solution } \mathrm{x} \text { ml of } \\
& \text { solution used. } \\
& \% \text { organic matter was determined by } \\
& \text { multiplying percentage organic carbon } \\
& (\% \mathrm{C}) \text { by } 1.724 \text {, that is, } \% \text { organic matter } \\
& =\% \mathrm{C} \times 1.724 .
\end{aligned}
$$

\section{Total Nitrogen Determination}

The method of Keeney and Nelson (1982) was followed. Five grams of air-dried and sieved (2 $\mathrm{mm}$ sieve) soil sample was fed into a $500 \mathrm{ml}$
Kjeldahl flask. A catalyst mixture with the following composition was prepared: $0.20 \mathrm{~g}$ selenium powder, $5.0 \mathrm{~g}$ lithium sulphate and 100 $\mathrm{ml}$ of $30 \%$ hydrogen peroxide. Two hundred millilitres $(200 \mathrm{ml})$ of conc. sulphuric acid was mixed with the catalyst and $100 \mathrm{ml}$ of this digestion mixture was added slowly to the sample in the Kjeldahl flask. The entire mixture was heated in a fume-cupboard until the digest was clear. This lasted for $2 \mathrm{~h}$. The digest was allowed to cool and subsequently $50 \mathrm{ml}$ was transferred into a $1000 \mathrm{ml}$ Kjeldahl flask containing $400 \mathrm{ml}$ distilled water. It was mixed thoroughly and allowed to settle until a clear solution was formed. One hundred milliliters $(100 \mathrm{ml})$ of $45 \%$ sodium hydroxide was added to the solution in the flask to make it alkaline and the flask immediately connected to the distillation apparatus. The ammonia was collected over $50 \mathrm{ml}$ of $2.5 \%$ boric acid solution contained in $250 \mathrm{ml}$ conical flask with 5 drops of mixed indicator (bromocresol green and methyl red mixed in ethanol). Two hundred milliliters $(200 \mathrm{ml})$ of the distillate was collected and titrated with standard $0.05 \mathrm{~N} \mathrm{HCl}$.

$\%$ Nitrogen was calculated with the formula:

$\% \mathrm{~N}=\frac{\operatorname{TxN} 14.01 \times 1}{1000 \quad \mathrm{~W}_{\mathrm{t}}}$

Where:

$\mathrm{T}=$ Sample titre

$\mathrm{N}=$ Acid normality

$\mathrm{W}_{\mathrm{t}}=$ Weight of soil sample used

Determination of $\mathrm{Ca}^{2+}, \mathrm{Na}^{+}, \mathrm{Mg}^{2+}$ and $\mathrm{K}^{+}$

The method of Black (1965) and AOAC (1970) was adopted in this analysis. Five grams of each soil sample was weighed into Whatman No. 1 filter paper fitted into a funnel on a leaching stand with $100 \mathrm{ml}$ volumetric flask to collect the leachate. The sample was leached with $1.00 \mathrm{~N}$ ammonium acetate solution and $100 \mathrm{ml}$ volume was collected.

For the determination of $\mathrm{Ca}^{2+}$ and $\mathrm{Mg}^{2+}$, ten milliliters $(10 \mathrm{ml})$ of the leachate was dispensed into a $100 \mathrm{ml}$ conical flask. This was followed by the addition of $10 \mathrm{ml}$ ammonium chloride solution to the flask.

The resulting solution was mixed well and $0.01 \mathrm{~g}$ of Eriochrome Black-T indicator was incorporated and titrated immediately with $1 \mathrm{~N}$ 
EDTA in the burette.

Calculation:

Tx N x $\underset{\text { Aliq. }}{\text { Vol. }} \frac{100}{w t}=$ Meq. $\mathrm{Ca}^{2+} \mathrm{Mg}^{2+} / 100 \mathrm{~g}$ of soil

Where

$\mathrm{T}=$ Sample titre

$\mathrm{Vol}=$ Volume of leachate collected originally

Aliq $=$ Aliquot of leachate titrated

$\mathrm{Wt}=$ Weight of soil sample leached.

Meq. $=$ Milliequivalent

For $\mathrm{Ca}^{2+}$ determination, ten milliliters of the leachate was pipetted into another $100 \mathrm{ml}$ conical flask. Thereafter $20 \mathrm{ml}$ of $20 \%$ potassium hydroxide was added and $0.01 \mathrm{~g}$ calcien indicator incorporated; the resulting solution was titrated with $0.01 \mathrm{~N}$ EDTA in a burette.

Calculation:

$$
\begin{aligned}
& \text { Meq.Ca }{ }^{2+} / 100 \mathrm{~g} \text { soil }=\mathrm{T} \times \mathrm{N} \times \frac{100}{\mathrm{Wt}} \times \frac{\mathrm{Vol}}{\text { Aliq. }} \\
& \text { Where: } \quad \mathrm{T}=\text { Sample titre } \\
& \mathrm{N}=\text { Normality of EDTA } \\
& \mathrm{Wt}=\text { Weight of soil sample used }
\end{aligned}
$$

Meq. $\mathrm{Mg}^{2+}$ was obtained by subtracting meq. $\mathrm{Ca}^{2+}$ from meq. $\mathrm{Ca}^{2+}+$ meq. $\mathrm{Mg}^{2+}$, that is, meq. $\mathrm{Ca}^{2+}+$ $\mathrm{Mg}^{2+}$ - meq. $\mathrm{Ca}^{2+}$

Sodium $\left(\mathrm{Na}^{+}\right)$and potassium $\left(\mathrm{K}^{+}\right)$were determined colorimetrically using a flame photometer (Jenway PEP7 Flame Photometer, Germany) from the remaining leachate.

\section{Sulphur Determination}

For the determination of sulphur, the method of Tabatabai and Bremner (1970) was adopted. Soil sample was finely ground and $0.1 \mathrm{~g}$ was weighed into a ceramic crucible. Subsequently $3 \mathrm{ml}$ sodium hypobromite solution $(\mathrm{NaOBr})$ was added and allowed to stand for $5 \mathrm{~min}$. The digestion mixture was placed on a laboratory hot plate and evaporated to dryness at $250{ }^{\circ} \mathrm{C}$. After cooling to room temperature, $3 \mathrm{ml}$ distilled water was added and the digest heated again for $30 \mathrm{~s}$. This was followed by agitation to dissolve the residue and then cooling to ambient temperature. It was then transferred quantitatively to a $10 \mathrm{ml}$ volumetric flask and more water was added to make the solution to volume in the volumetric flask. Particles that could interfere with the analysis were filtered off before the absorbance was read at 420 $\mathrm{nm}$ in a colorimeter (Jenway 6051, Germany).

\section{Determination of Phosphorus in Soil Sample}

The method of Black (1965) was followed. Two grams of air - dried and sieved soil was weighed into a test tube and to the test tube was added 20 $\mathrm{ml}$ of $0.03 \mathrm{~N}$ ammonium fluoride $\left(\mathrm{NH}_{4} \mathrm{~F}\right)$ in $0.1 \mathrm{~N}$ $\mathrm{HCl}$ and the tube stoppered. The tube was agitated for $1 \mathrm{~min}$, allowed to settle and subsequently filtered using a filter paper. One milliliter $(1 \mathrm{ml})$ of the filtrate was pipetted into another test tube. To this test tube was added $7.0 \mathrm{ml}$ of distilled water, $1.0 \mathrm{ml}$ of $2.5 \%$ ammonium molybdate and $1.0 \mathrm{ml}$ of $2 \%$ ascorbic acid, bringing the total volume to $10 \mathrm{ml}$. The solution was mixed very well and placed in a beaker of boiling water for $3 \mathrm{~min}$. The optical density was read at $620 \mathrm{~nm}$ using a colorimeter (Jenway 6051 Colorimeter, Germany).

\section{Soil Moisture Content Determination}

Two porcelain basins were weighed and the weights recorded. Twenty ( $20 \mathrm{~g})$ grams of each of the wet soil samples (both the control and polluted samples) was weighed in duplicate into each of the basins. The samples were dried in an oven at 105 ${ }^{\circ} \mathrm{C}$ for $24 \mathrm{~h}$ and later cooled in a desiccator. The dry soil samples were re-weighed and the weights obtained by subtracting the weight of the empty basin from the combined weight of the basin and the dry soil.

The $\%$ soil moisture content $=$ Moist weight-Dry weight x 100

Moist weight

\section{Soil $\mathrm{pH}$ in Distilled Water}

The method of Black (1965) was followed. A 20.0 $\mathrm{g}$ sample of the soil was put into a $50 \mathrm{ml}$ beaker containing $20 \mathrm{ml}$ of distilled water. The mixture was allowed to stand for $30 \mathrm{~min}$, stirring occasionally with a glass rod. The electrodes of the $\mathrm{pH}$ meter were inserted into the partly settled suspension and the $\mathrm{pH}$ measured. 


\section{Determination of the Levels of Transition Elements in the Crude Oil}

This was done following the methods of Black (1965). One millilitre $(1 \mathrm{ml})$ of the crude oil was pipetted into a $250 \mathrm{ml}$ conical flask and $40 \mathrm{ml}$ of 1:1 $\mathrm{HNO}_{3} /$ perchloric acid was added and allowed to stand for $24 \mathrm{hr}$. The digestion mixture was placed on a heater inside a fume cupboard and heated to eliminate the carbon content until white fumes appeared indicating complete digestion. It was heated further to a near dryness and cooled. Distilled water was added and $100 \mathrm{ml}$ of the digest filtered into a volumetric flask. The filtrate was used for the determination of the levels of iron, cobalt, nickel and copper.

\section{(a) Iron Determination}

\section{(Orthophenanthroline Method)}

Ten milliliters $(10 \mathrm{ml})$ of the crude oil extract was pipetted into a $50 \mathrm{ml}$ volumetric flask. To the extract was added $2 \mathrm{ml}$ of $10 \%$ hydroxylamine hydrochloride solution, $20 \mathrm{ml}$ of $10 \%$ sodium citrate and $2 \mathrm{ml}$ of $0.25 \%$ orthophenanthroline. The solution was made up to $50 \mathrm{ml}$ volume with distilled water and allowed to stay for $24 \mathrm{~h}$ for colour development.

The absorbance was read at $510 \mathrm{~nm}$ and the quantity of iron in $\mathrm{mg} /$ of the crude oil calculated as:

Quantity in $\mathrm{mg} / \mathrm{L}=$

Absorbance $x$

Gf x $\quad \frac{\text { Total extract }}{\text { Aliquot taken }} \times \frac{1}{\text { Weight of sample }}$

Where:

$\mathrm{Gf}=$ slope of standard curve prepared by plotting the absorbance of pure iron metal against their concentrations

\section{(b) Nickel Determination (Back-titration with $\mathrm{ZnSO}_{4}$ )}

Ten milliliters of the extract was introduced into a $250 \mathrm{ml}$ conical flask containing $50 \mathrm{ml}$ of distilled water. To the volume were added, $30-35 \mathrm{ml}$ of $0.0 \mathrm{I}$ $\mathrm{N}$ EDTA through a burette, $5 \mathrm{ml}$ of ammonia buffer solution and a pinch of Eriochrome Black$\mathrm{T}(\mathrm{EBT})$ indicator.
The excess EDTA was titrated with $\mathrm{N} \mathrm{ZnSO}_{4}$ solution until the colour changed from blue to wine red end point.

\section{Calculation:}

Quantity of nickel in the crude oil $(\mathrm{mg} / \mathrm{L})=$ Titre $\mathrm{x}$ normality of metal $\left(\mathrm{ZnSO}_{4}\right) \mathrm{x}$ Equiv. weight of metal $\times \frac{\text { Total extract }}{\text { Aliquot taken }} \times \frac{1}{\text { Weight of sample }}$

Where:

Equivalent weight of metal =

Molar mass of metal

Valency of metal

\section{(c) Determination of Cobalt}

Ten milliliters $(10 \mathrm{ml})$ of the crude oil extract was added to a $250 \mathrm{ml}$ conical flask containing $50 \mathrm{ml}$ of distilled water. Thereafter, $10 \mathrm{ml}$ of ammonia buffer solution, $1 \mathrm{ml}$ of $0.05 \%$ orthophenanthroline, $5 \mathrm{ml}$ of $0.01 \mathrm{~N}$ EDTA and a pinch of Eriochrome Black- $\mathrm{T}$ indicator were added. This was back - titrated with $0.01 \mathrm{~N} \mathrm{ZnSO}_{4}$ to a reddish end point.

\section{Calculation:}

Quantity of cobalt in the crude oil $(\mathrm{ml} / \mathrm{L})=$ Titre $\mathrm{x}$ normality of metal $\mathrm{x}$ equivalent weight of metal $\mathrm{x}$ Total extract

$\overline{\text { Aliquot taken }} \times \overline{\text { Weight of sample }}$

Where:

Equivalent weight of metal = Molar mass of metal

Valency of metal

\section{(d) Copper Determination}

Ten milliliters $(10 \mathrm{ml})$ of the crude oil extract was pipetted into a test tube. To the test tube were added $5 \mathrm{ml}$ of $2 \mathrm{~N} \mathrm{NH}_{4} \mathrm{OH}$ solution and $5 \mathrm{ml}$ of $0.05 \mathrm{~N}$ potassium ferrocyanide solution. After mixing, the test tube was allowed to stand for $2 \mathrm{~h}$, and then the absorbance was read at $400 \mathrm{~nm}$.

\section{Calculation}

Total copper in the crude oil $(\mathrm{mg} / \mathrm{L})=$ 
Absorbance $\mathrm{x}$ slope of standard curve $\mathrm{x}$

Total extract 1

Aliquot taken

Weight of sample

\section{Statistical Analysis}

Data analysis was carried out using a one-way analysis of variance(ANOVA) and the difference was done by comparing tests with $\mathrm{P}<0.05$.

\section{RESULTS}

Effects of Crude Oil on Soil Respiration (Microbial Respiration) and Phospholipid Levels

Results of these assays are presented in figures 1 and 2. Soil respiration was quantified in terms of the level of $\mathrm{CO}_{2}$ evolved from the soil over a specified period of time. High levels of crude oil significantly $(\mathrm{P}<0.05)$ reduced the levels of $\mathrm{CO}_{2}$ evolution (Figure 1) and phospholipids (Figure 2) in the soil samples. Exposure time of the crude oil to microorganisms positively affected the levels of $\mathrm{CO}_{2}$ and phospholipids in the soil. For instance, the levels of both substances after eight weeks of incubation were much higher than their levels after four weeks (Figures 1 and 2). The level of $\mathrm{CO}_{2}$ in the control sample after four weeks of incubation was higher than the levels in the polluted (test) samples. However after eight weeks of incubation the level of $\mathrm{CO}_{2}$ in the control became lower than its level in each of the test samples (Figure 1). Maximum $\mathrm{CO}_{2}$ levels in the test samples occurred at $0.5 \%$ and $1 \%$ crude oil levels in both the four-week and eight-week incubated samples. This trend also occurred with the phospholipid levels - maximum levels were also obtained at $0.5 \%$ and $1 \%$ crude oil concentrations. Correlation analysis using the Pearson's correlation model (Figure 3) showed a positive correlation between soil $\mathrm{CO}_{2}$ and phospholipids (correlation coefficient $=0.74$ ).

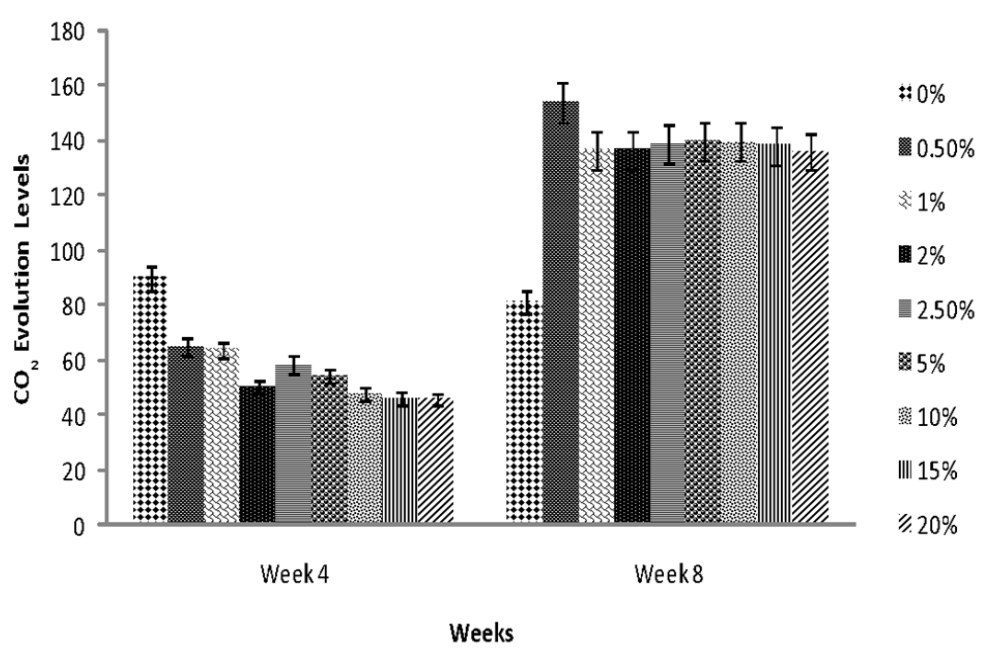

Figure 1: Effects of Crude Oil on Soil Respiration 


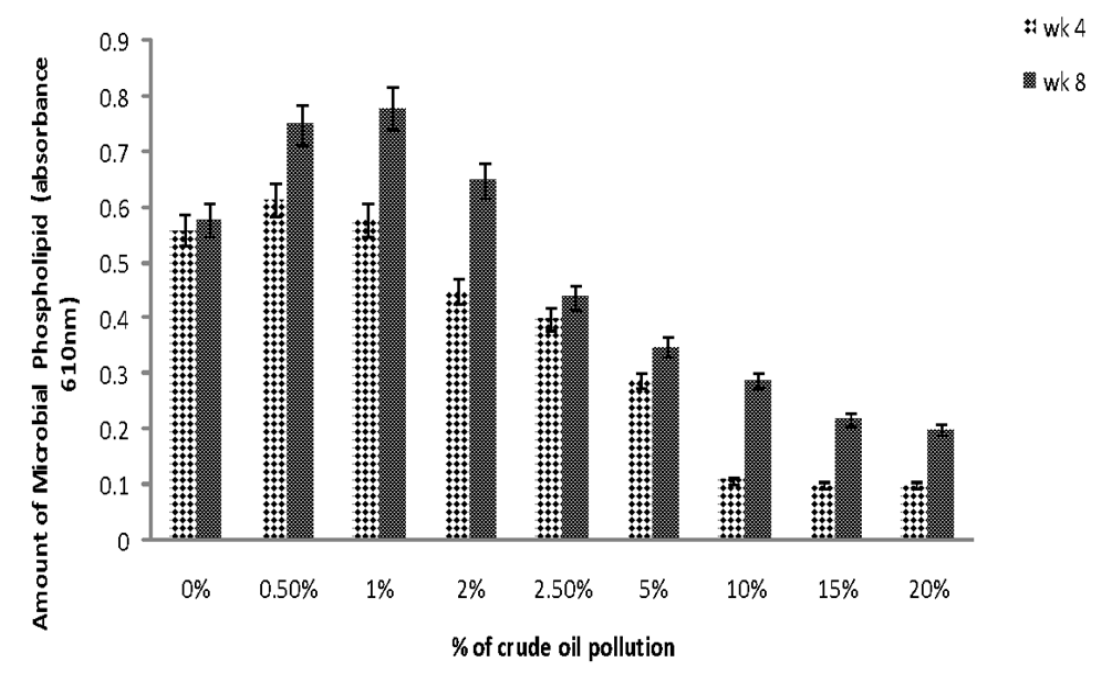

Figure 2: Effects of Varying Levels of Crude Oil on Soil Microbial Phospholipids (nm/g of soil)

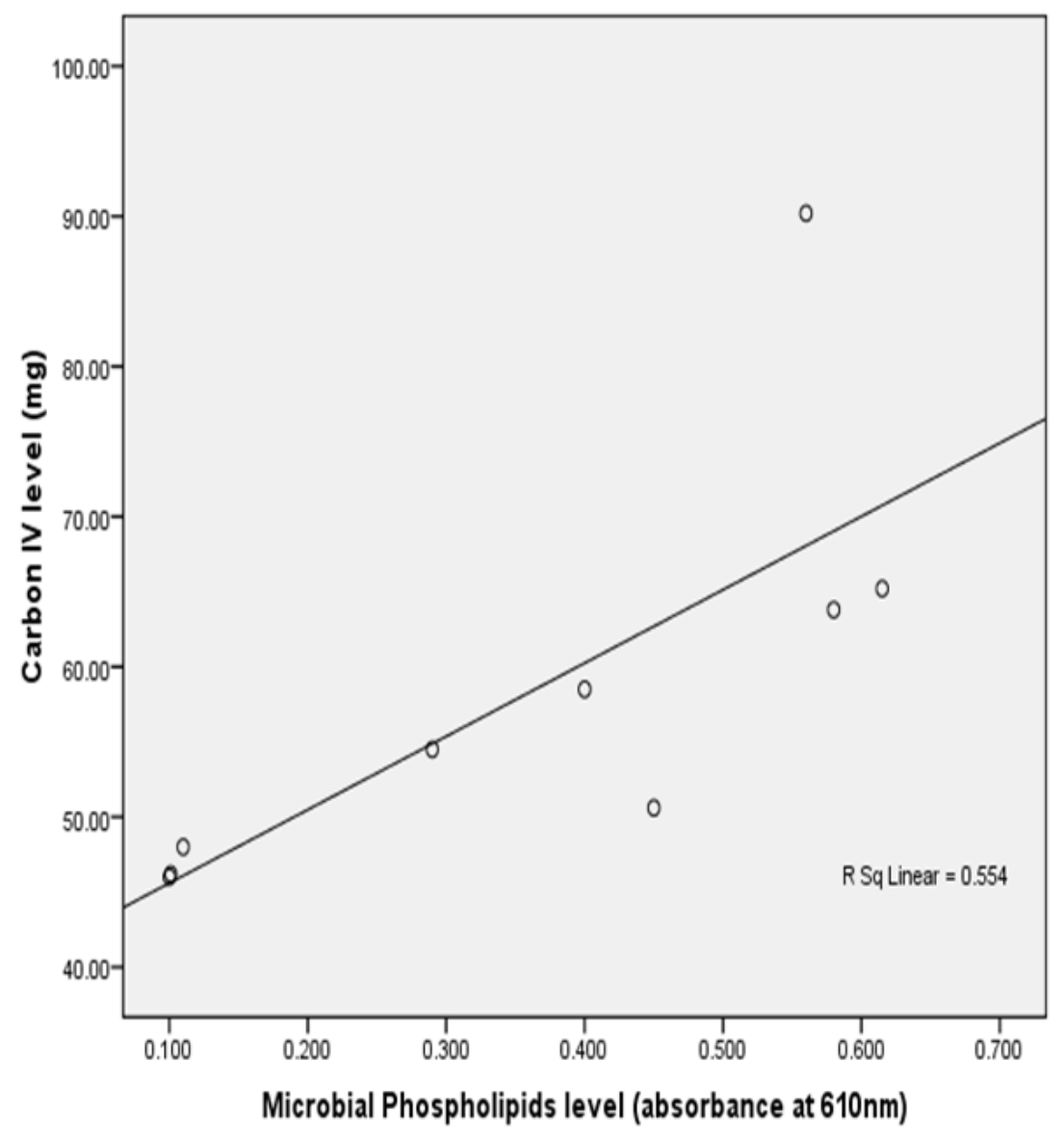

Figure 3: Relationship between Microbial Phospholipid and $\mathrm{CO}_{2}$ Evolution from Crude Oil contaminated Soil Samples.

Effects of Crude Oil on Soil pH, Moisture and Organic Matter Levels

These are depicted in figure 4 . With the exception of $\mathrm{pH}$ which was almost stable in all the levels of crude oil contamination, soil moisture and organic matter increased with increase in crude oil level. 


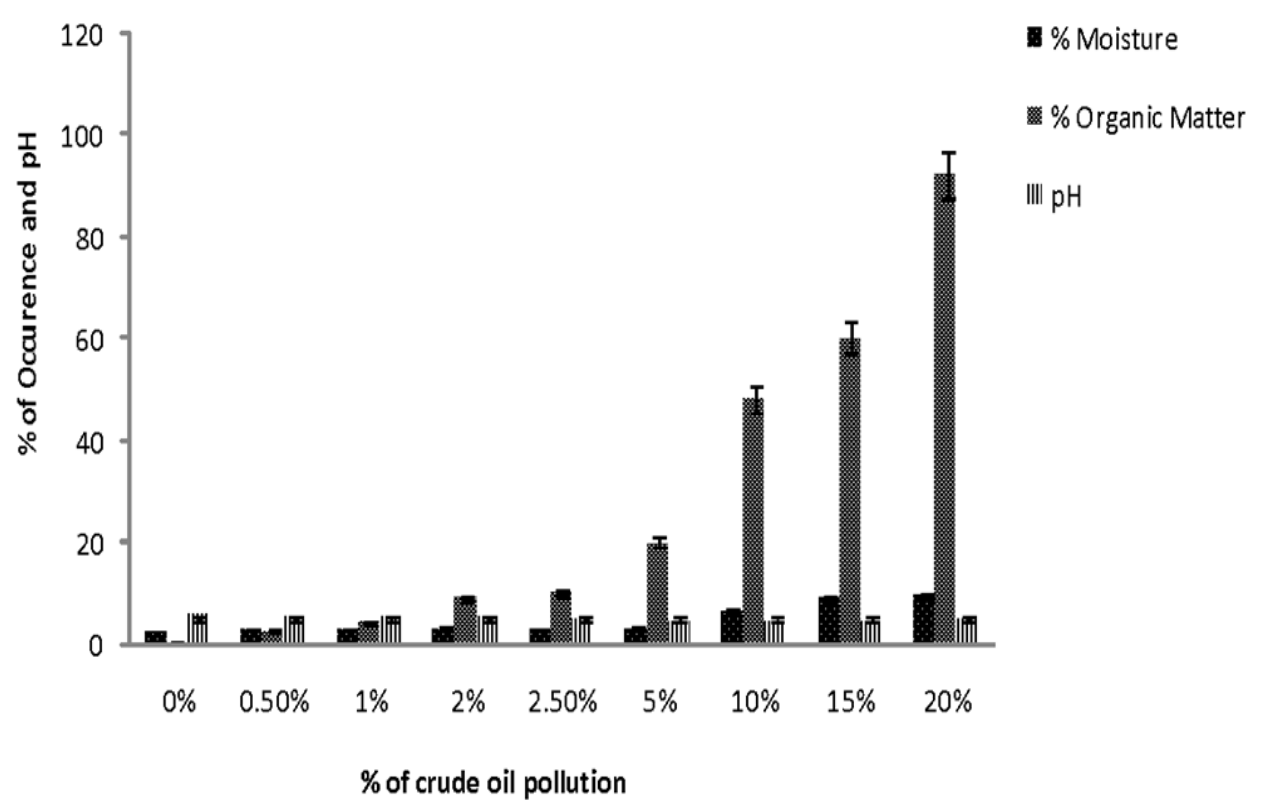

Figure 4: Effects of Crude Oil on pH, Moisture and Organic Matter Levels of the Soil

Effect on Soil Macronutrients- Carbon, increase in crude oil level but the reverse was the Nitrogen, Calcium, Sodium, Potassium, case with nitrogen and other macronutrients Phosphorus, Magnesium and Sulphur which decreased as crude oil dose increased Soil organic carbon (Figure 5) increased with (Figures 6 and 7).

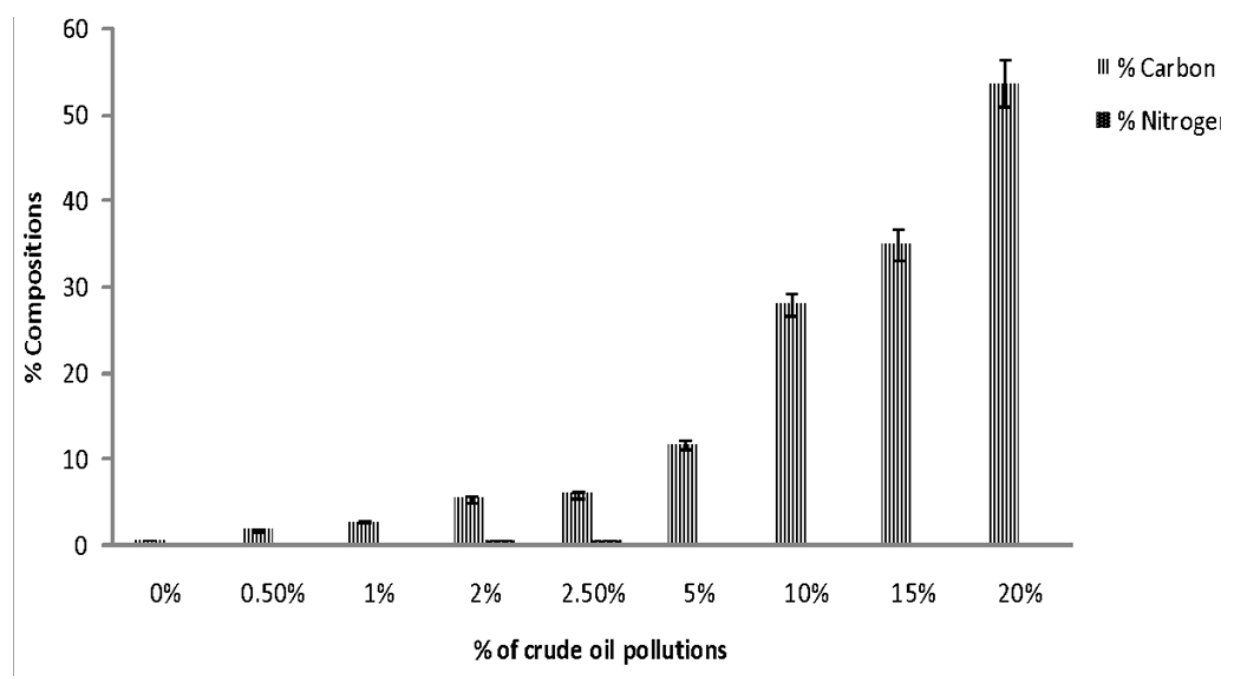

Figure 5: Effect of Crude Oil on the Percentage Composition of Soil Carbon and Nitrogen 


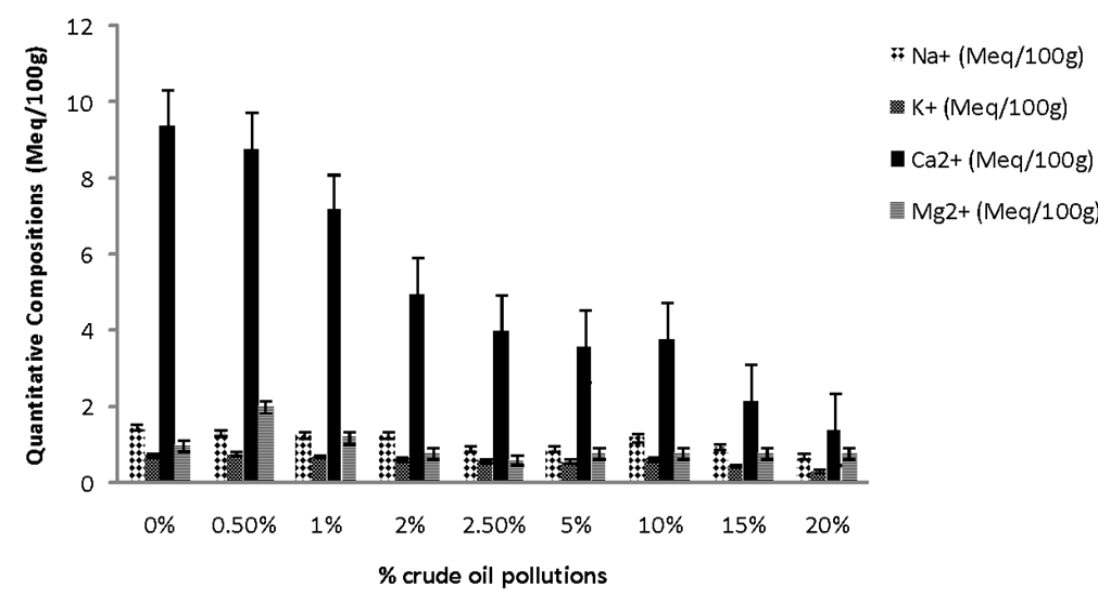

Figure 6: Effect of Crude Oil on the Quantitative Composition of Soil Macroelements

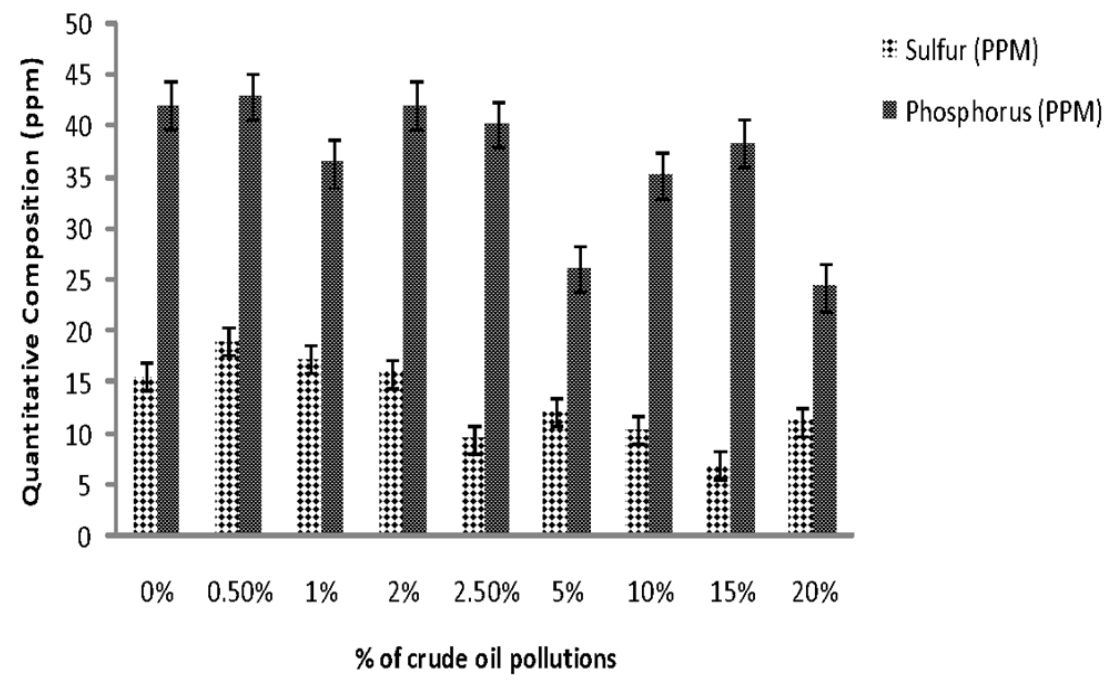

Figure 7: Effect of Crude Oil on the Quantitative Composition of Soil Macroelements

Quantitative Composition of Some contained significant $(\mathrm{P}<0.05)$ levels of iron, Transition Elements in the Crude Oil copper, cobaltand nickel.

\section{Sample}

This is presented in table 1 . The crude oil

Table 1: Quantitative Composition of Some Transition Elements in the Crude Oil Sample

\begin{tabular}{lllll}
\hline Elements & $\mathrm{Fe}$ & $\mathrm{Cu}$ & $\mathrm{Co}$ & $\mathrm{Ni}$ \\
\hline $\begin{array}{l}\text { Composition } \\
\text { (mg/L of crude) }\end{array}$ & $2.995 \pm 0.01$ & $5.194 \pm 0.11$ & $1.179 \pm 0.02$ & $1.467 \pm 0.13$ \\
\hline
\end{tabular}




\section{DISCUSSION}

Crude oil had significant effects on some physicochemical properties of the soil. Organic matter level, for instance, increased significantly $(\mathrm{P}<0.05)$ with increase in crude oil level, even though this increase was caused by the introduction of organic carbon into the soil by the crude oil. Increase in organic matter under normal circumstances is expected to improve soil fertility but in this case because the increase was crude oilassociated it rather decreased soil fertility. This is because the oil seals up soil pore spaces preventing water and air movement into the soil, lowers biological activity and disrupts biochemical conversions necessary to make mineral nutrients available to plants. Soil $\mathrm{pH}$ and moisture were not significantly affected by the oil.

Crude oil had a dose-dependent inhibitory effect on the levels of macroelements in the soil, with the exception of organic carbon which increased progressively with increase in crude oil level. There were significant reductions $(\mathrm{P}<0.05)$ in the levels of soil $\mathrm{N}_{2}, \mathrm{Na}, \mathrm{K}, \mathrm{Ca}$, and $\mathrm{S}$ as crude oil level increased, when compared to their levels in the uncontaminated control (Figures 5-7). It was only in magnesium and phosphorus that the effect was not pronounced. This may be because crude oil binds most of these mineral nutrients making them unavailable. A likely mechanism through which crude oil does this is through the transition element constituents. The crude oil is rich in transition elements (Table 1) and these elements are characterized by the possession of partially filled $d$ or $f$ orbitals in any common oxidation state. Through these free orbitals, they form coordinate bonds and coordinate complexes with ligands (eg. $\mathrm{NH}_{3}, \mathrm{H}_{2} \mathrm{O}, \mathrm{NO}_{2}$ etc) or other elements (eg $\mathrm{K}, \mathrm{Ca}$, $\mathrm{Mg}$ etc) (Coxon et al., 1980). When such complexes are formed, the bound ions will lose their ionic properties and will not be detectable in solution. Okolo et al. (2005) also reported that oil pollution reduced the levels of soil nitrate and phosphorus but they did not investigate the effects on other macroelemnts. Wyszkowski et al. (2001) had earlier reported an increase in the levels of nitrogen, phosphorus and potassium in crude oil-polluted soil but in their case the soil was amended with NPK compound fertilizer.
The oil reduced the rate of soil respiration and the level of microbial phospolipids in a dosedependent manner (Figures 1 and 2). Phospholipids are a component of all cell membranes and they remain in constant proportion to the bacterial biomass and rapidly disappear after cell death (Peterson et al. 1991). According to Frostegard et al. (1991), phospholipid levels are used to measure total microbial biomass, activity and metabolic status. Correlation analysis using the Pearson's correlation model (Figure 3) showed a positive correlation between soil $\mathrm{CO}_{2}$ and phospholipid (correlation coefficient $=0.74)$.

\section{CONCLUSION}

This study has revealed some of the deleterious effects of crude oil pollution on soil microbial respiration and physicochemical properties. Further research into more of the mechanisms by which this natural resource impoverishes the soil will help environmental managers to design strategies for the remediation of crude oil contaminated soils.

\section{ACKNOWLEDGEMENT}

The authors wish to acknowledge the assistance given by the Department of Microbiology, University of Nigeria, Nsukka through the provision of some facilities used for the work.

\section{REFERENCES}

Adoki, A. and T. Orugbani (2007). Influence of nitrogenous fertilizer plant effluents on growth of selected farm crops in soils polluted with crude petroleum hydrocarbons. African Journal of Agricultural Research, 2(11): 569-573.

Association of Official Analytical Chemists (AOAC) (1970). Official Methods of Analysis, $2^{\text {nd }}$ Edition. Washington D.C.

Black, C.A., 1965. Methods of Soil Analysis. Agronomy No 9, Part 2. American Society of Agronomy, Madison, Wisconsin.

Chaineau, C.H., J.L. Morel and Oudot, J. (2000). Biodegradation of fuel oil hydrocarbons in the rhizosphere of maize. Journal of Environmental Quality, 29: 549-578.

Coxon, J.M., Fergusson, J.E. and Phillips, L.F. (1980). First Year Chemistry. Edward 
Eze et al.: Changes in Soil Microbial Respiration and Physicochemical Properties

Arnold (London). Pp.116-216.

Eze, C.N., J.N. Maduka, J.C.Ogbonna and E.A. Eze (2013). Effects of Bonny light crude oil contamination on the germination, shoot growth and rhizobacterial flora of Vigna unguiculata and Arachis bypogea grown in sandy loam soil. Scientific Research andEssays, 8(2):99-107

Findlay, R.H., King, G.M. and Watling, L. (1989). Efficacy of phospholipids analysis in determining microbial biomass in sediments. Applied Environmental Microbiology, 55: 2888-2893.

Frostegard, A., Tunlid, A. and Bath, E. (1991). Microbial biomass measured as total lipid phosphate in soils of different organic content. Journal of Microbiological Methods, 13(14): 151-163.

Ikuesan, F.A. (2017). Microbial response to varying concentrations of crude oil pollution of agricultural soils in Ondo state, Nigeria. Microbiology Research Journal International, 22 (4): 1-8.

Isermeyer, H. (1952). Eine eifache Methode zur Bestimmung der Bodenatmung und demKarbonate im Boden. Z Pflanzenernah Bodenk, 56:26-38

Keeney, D.R. and Nelson, D.W. (1982). Determination of mineral (inorganic) nitrogen. In, Methods of Soil Analysis, Vol.2. Page A.L., Miller R.H. and Keeney, D.R. (eds). Am. Soc. Agron., Madison. Pp. 643.

Mariana, M., Mihai, T., Veronica, T., Vera, C., Georgiana, P. and Irina, C. (2010). An assessment of the effects crude oil pollution on soil properties. Annals of Food Science and Technology, 11(1): 1-6.

McOrist, S. and Lenghaus, C. (1992). Mortalities of little penguins (Eudiptuta minor) following exposure to crude oil. Veterinary Records, 130:161.

Odo, C.K., Zabbey, N. Sam, K. and Eze, C. N. (2019). Status, progress and challenges of phytoremediation: An African scenario. Journal of Environmental Management, 237: 365-378

Okolo, J.C., Amadi, E.N. and Odu, C.T.I. (2005). Effects of soil treatments containing poultry manure on crude oil degradation in a sandy loam soil. Applied Ecology and Environmental Research, 3(1): 47-53.

Petersen, S.O., Henriksen, K., Blackburu, T.H. and King, G.M. (1991). A comparison of phospholipids and chloroform fumigation analyses for biomass in soil, potentials and limitations. FEMS MicrobialEcology, 85: 257-268.

Sulaiman A., Dominic B., Graeme I. (2015). Effects of hydrocarbon contamination on soil microbial community and enzyme activity. Journal of King Saud UniversityScience, 27(1):31-41.

Tabatabai, M.A. and Bremner, J.M. (1970). Comparison of some methods for determination of total sulphur in soils. Soil Science Society American Proceedings, 34: 317-420.

Walkley, A. and Black, I.A. (1934). An examination of the Degtjareff Method for determining soil organic matter and proposed modification of the chromic acid titration method. Soil Science, 37:2938.

Wyszkowski, J., Kucharski, J., Jastrzebska, E. and Illasko, A. (2001). The biological properties of the soil as influenced by chromium contamination. Polish Journal of Environmental Studies, 10: 37-42. 